\title{
Needs Analysis: Development of Character-integrated Problem Solving Model for Chemistry Lessons in Senior High Schools
}

\author{
Mauliza ${ }^{1}$, Nurhafidhah ${ }^{*}$, Joko Hariadi². \\ ${ }^{1}$ Department of Chemistry Education, Samudra University, Langsa, Indonesia. \\ ${ }^{2}$ Department of Indonesian Language Education, Samudra University, Langsa, Indonesia.
}

DOI: $\underline{10.29303 / \text { jppipa.v8i1.1053 }}$

\section{Article Info}

Received: October 20, 2021

Revised: January 18, 2022

Accepted: January 22, 2022

Published: January 31, 2022

\begin{abstract}
Problem-solving learning models can not only improve cognitive and psychomotor aspects but also affective aspects. One of the affective aspects is character. This study aims to analyze the needs as a basis for developing a character-integrated problem-solving model in high school. This study uses a survey method. The research population is all Senior High School (SMA) and chemistry teachers in Langsa city. The research sample was determined by purposive sampling technique, obtained 4 Senior high schools, along with 7 chemistry teachers. Data were collected by using questionnaires, observation, and interview techniques. The type of questionnaire used is an open-closed questionnaire, consisting of 30 questions. The specific indicators used to reveal the need for developing a character-integrated problem solving are teacher readiness, teacher's need, student's need, and Support. Data were analyzed descriptively. The results show that the development of a character-integrated problem-solving model for chemistry lessons in senior high school is very much needed. The findings of this study are in accordance with the findings of previous studies.
\end{abstract}

Keywords: Problem solving; Character; Learning model; Chemistry

Citation: Mauliza, M., Nurhafidhah, N., \& Hariadi, J. (2022). Needs Analysis: Development of Character-integrated Problem Solving Model for Chemistry Lessons in Senior High Schools. Jurnal Penelitian Pendidikan IPA, 8(1), 336340. https://doi.org/10.29303/jppipa.v8i1.1053

\section{Introduction}

Problem solving learning model can not only improve cognitive and psychomotor aspects but also affective aspects. In accordance with the statement of Carolin, et al. (2015) that problem solving learning can improve learning achievement in attitude competence. Problem solving model is considered an accurate learning model for students to solve problems (Astra, et al., 2020; Partayasa, 2020).

One of the affective aspects developed in education is character values. Learning innovation in the industrial era 4.0 emphasizes strengthening character based on information technology (Wijaya and Tulak, 2019). However, the problem-solving model is still challenging to apply in the learning process. This statement is reinforced by the opinion of the teacher, who gave a positive response to the statement (Lestari, et al., 2021).

Character education is something that is important to form a quality generation (Nurhafidhah, et al., 2018). The value of character education in classroom learning, both in teaching materials and in the learning process, needs to be properly instilled in students, which will later be formed into a character (Nurhafidhah, et al., 2021).

The integration of character values in learning media has been widely studied. However, the integration of character values has not been found explicitly in a learning process, for example in a learning model. Some of the character education learning models that have been developed are very limited in their use on certain materials, as Mulyasa (2016) stated that the character education model is carried out using the following models: 1 ) habituation 
and exemplary, 2) contextual teaching and learning, 3) role playing, and 4) participatory learning. Sadia et al. (2013) said, one of the science learning models that contribute significantly to the character development of students is the problem-solving learning model.

Tanjung and Wibowo (2013) stated that the problem-solving learning model with character integration has a great influence on students' physics learning outcomes. In fact, science learning in schools, especially in chemistry learning is still focused on the teacher as the main source of knowledge with the lecture, assignment, and exercise methods (Putri, et al., 2015). Based on the results of interviews with several chemistry teachers at Langsa City Senior High School, the teacher stated that it was very difficult to integrate character values in chemistry learning. Character values can be instilled by teachers only in certain materials and activities, such as when students do assignments, when discussing material related to the natural surroundings and everyday life. Thus, the teacher really hopes that there will be a learning model that is suitable for chemistry learning as well as being able to develop the character values of students. Purpose of This research to analyze the needs as a basis for developing a character- integrated problem-solving model in high school.

The urgency of the research, it is necessary to analyze the needs of character-integrated problemsolving model. The research is important to be carried out with the aim of being initial data to determine the readiness and needs of the users of the developed model so that the character-integrated problem-solving model can be applied in the long term and there are no significant obstacles in its application.

\section{Method}

This study uses a survey method. The survey method is used to conduct needs analysis in the context of developing a character-integrated problem-solving model. The survey method can be used as a basis for developing learning products (Borg \& Gall, 2005). The population of this study were all senior high school and chemistry teachers in Langsa city. The sampling of the research was determined by using the purposive sampling technique. The consideration for selecting the sample is that schools have applied problem solving models in chemistry learning. The research sample was 7 chemistry teachers from SMAN 2, SMAN 3, SMAN 4, and SMA Cut Nyak Dhien Langsa.

Research data were collected by questionnaires, observations and interviews. The questionnaire technique was used to collect data on needs covering aspects of teacher readiness, teacher needs, support (infrastructure, policies, and leadership), and student needs. The interview technique was used to obtain supporting data from the questionnaire data related to responses to obstacles in the application of the learning model, while the observation technique was used to observe the supporting devices owned by the teacher in the learning process that the teacher had done. The research data were analyzed using descriptive analysis techniques. The following is a research flow chart.

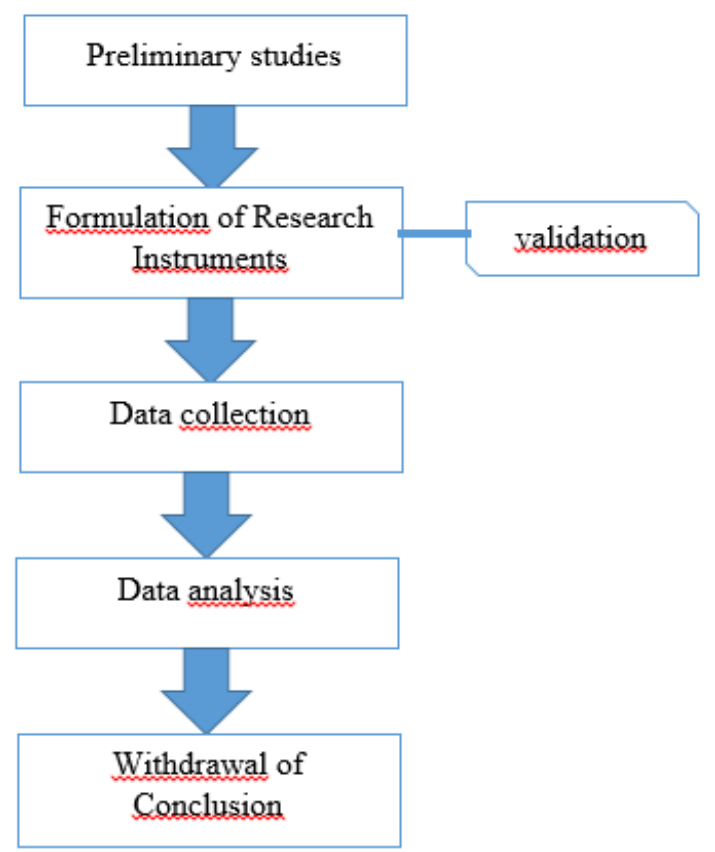

Figure 1. A Research Flow Chart

\section{Result and Discussion}

\section{Teacher Readiness}

The data obtained from the results of distributing questionnaires include teacher readiness. Teachers' readiness perceptions can be explored from a multidimensional perspective (Nikolopoulou, et al., 2021). Teacher readiness needs to be known to ensure that the character-integrated problem-solving model that will be developed can be used by the teacher without any problems. According to statement Anoba \& Cahapay (2020) the readiness of the teachers is sensitive to contextual issues. Many studies have identified the interplay between readiness and various factors. 4 of 7 teachers as a sample stated that they often apply learning models in the learning process. The learning models that have been implemented include: Problem based learning, Contextual teaching and learning, learning cycle model, Portfolio-based learning, ScienceTechnology-Society learning model, Problem solving, Cooperative learning, Inquiry based learning, and Project based learning.

The learning model is applied by the teacher to several topics of chemistry such as basic laws of chemistry and stoichiometry, atomic structure, systems and properties of the periodic table of elements, 
chemical bonds, redox and electrochemical reactions, chemical elements, colloids, hydrocarbons, macromolecules (carbohydrates, proteins, and fats), colligative properties of the solution. From the learning model that has been applied, teachers can develop students' skills in language, numeracy and science skills. This information shows that teachers have readiness in implementing a new learning model that will be developed.

Teacher readiness is also known from the teacher's answers to questions about the obstacles experienced by teachers in implementing a learning model. This information becomes input for researchers in developing a character-integrated problem-solving model. The obstacles faced by teachers include: (1) Less allocation of learning time; (2) Inadequate facilities; (3) Various student abilities; (4) Students' interest and motivation towards the model and subject matter; (5) Hard to get chemicals; (6) The basic ability of students who are still lacking.

\section{The Teacher's Need}

The development of an integrated problemsolving model with character needs to consider the needs of the teacher. This is because the teacher's needs are a consideration whether or not a learning model is developed. Arka (2020) states that due to the paradigm shift in the educational process, an educational model is needed that is able to accommodate the development of student competencies. Competence of knowledge, skills, values, attitudes, appreciation must be possessed by students and can appear in their professional performance.

The teacher stated that not all learning models that have been applied can overcome the learning problems faced by the teacher, according to the answers to the questionnaire, $57 \%$ of teachers chose the answer sometimes (figure 2). Therefore, the development of learning models needs to be done.

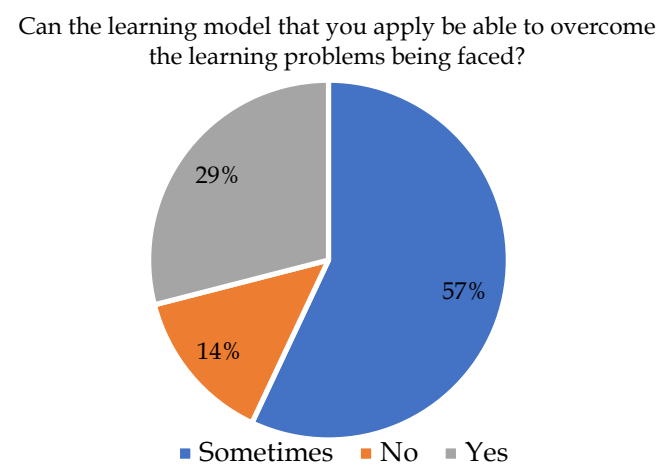

Figure 2. Learning Models Solve Learning Problems

In another question, 4 out of 7 teachers stated that the learning model that had been applied had contributed to the character development of students. The teacher states that learning models that can help develop the character of students include Problem based learning, Contextual teaching and learning, Science-Technology-Society learning models, Problem solving, Cooperative learning, Inquiry based learning, and Project based learning. Andriani and Wakhudin (2020) say that character education can be inserted in any learning but with a fun learning model.

The results of the analysis of the teacher's questionnaire answers also showed that 5 out of 7 teachers stated that the development of an integrated character learning model needed to be done (figure 4). In line with the opinion of the teacher, Supriadi, et al. (2020) in his research results stated that the implementation of problem-based learning in the Environmental Chemistry course at the Chemistry Education Study Program FKIP could significantly develop the character of students. Components of character include attitudes, interests, values, and selfconcept significantly contribute to the character of students.

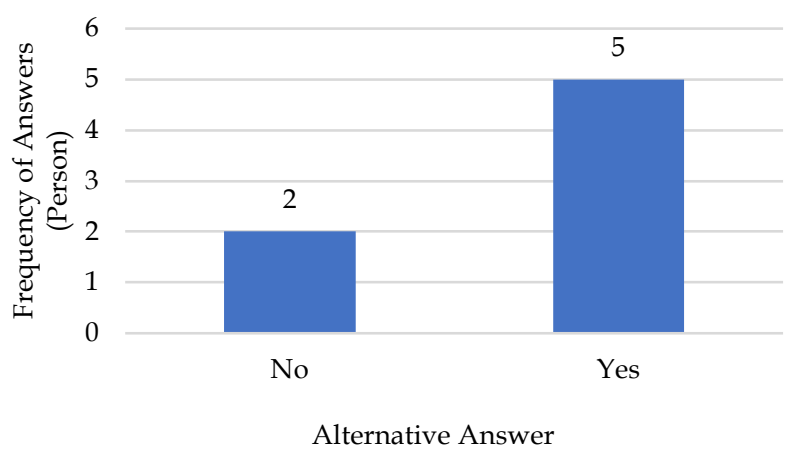

Figure 3. The Urgency of Developing Character-Integrated Problem-Solving Learning Model

The teacher's needs related to strengthening student character are known from the answers to the questionnaire according to the graph in Figure 4.

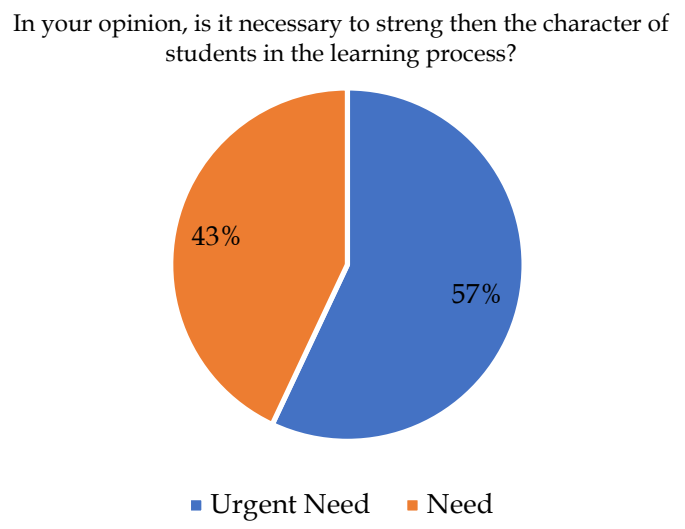

Figure 4. The Urgency of Character Strengthening 
The teacher provides character strengthening to students in the learning process through activities such as: giving rewards, giving punishments, checking student discipline, conducting student affective evaluations, discussions, field trips. In the next questionnaire question, the character values of students that the teacher wants to develop in the learning process, especially in chemistry subjects are religious, honest, tolerant, disciplined, hardworking, creative, independent, democratic, curiosity, national spirit, love for the homeland, appreciate achievement, communicative, love peace, love to read, care for the environment, care about social, and be responsible.

\section{Support (Infrastructure, School Policies, and School Principals)}

Aspects of support analyzed in the research are infrastructure such as buildings and services for teachers and students, school policies, and support from school principals. Infrastructure support is known from direct observation during the researcher's visit to the sampled school.

The lack of optimism in the management of supporting facilities and infrastructure for learning can be a factor in the results that are not good in the development of students (Mentari, et al., 2021). Each school has adequate infrastructure according to the standards of public schools in general. In addition, 6 out of 7 schools provide guidance and counseling services.

In terms of services and school policies, all the schools that were sampled held extracurricular activities and other routine activities, such as: flag ceremonies, praying, singing obligatory/regional songs, reading non-lesson books, working together to clean the school environment, and praying together. Likewise, the vision/mission of the schools that were sampled entirely contained strengthening character values.

In addition to infrastructure support and school policies, the development and application of a character-integrated problem-solving learning model also requires support from the leadership, namely the principal. Based on the teacher's response, it is known that the principal provides very adequate support for the implementation of the learning model that is carried out in the classroom. In fact, the principal establishes policies related to strengthening student character values through activities such as: (1) Welcoming the arrival of students in the morning; (2) the principal directs every teacher to always include strengthening character education in the classroom; (3) Giving appreciation in the form of gifts; (4) implementing the Life Skills program for students; (5) Establish a counseling guidance service

\section{The Student's Need}

The development of a character-integrated problem-solving learning model is needed if students show difficulties in implementing and developing their character. In addition, based on the teacher's perception, the character values of students affect learning outcomes. In fact, the value of character for students is very important. The teacher states that the character values that dominate the behavior of students are religious, disciplined, communicative, caring for the environment, responsible, independent, communicative, tolerant, democratic, curiosity, love for the homeland, respect for achievement, honest social care, discipline, hard work, and creative. Meanwhile, Siregar (2021) states that students also needed a learning model that could maximize their translation skills, a learning model that could solve the translation problems they found and a learning model that could maximally motivate students to work in groups.

The problem-solving model is a presentation method with provide problems as non-discussion to be analyzed and synthesized. It was an attempt to find solutions or answers made by students (Nurlaily, et al., 2019; Effendi \& Hendriyani, 2020; Zaki, et al., 2020). In the last question in the questionnaire, the teacher stated several main factors that influenced the character values of students, namely: (1) Family environment; (2) Life experience; (3) School environment; (4) Community environment.

\section{Conclusion}

Based on the results of the study, it can be concluded that the development of a characterintegrated problem-solving learning model for chemistry lessons in senior high school is needed. This is viewed from: a) aspects of teacher readiness who are able to apply a learning model, $b$ ) teacher needs stating the need to develop a character-integrated problemsolving learning model, c) aspects of infrastructure support, policies and school principals, and d) student needs for the formation of very important character.

\section{Acknowledgements}

This research was supported by Universitas Samudra and Institute of Research, Community Service and Quality Assurance (LPPP-PM) of Universitas Samudra as a Research of excellent base (PDU) 2021 based on contract number: 270.51/UN54.6/PG/ 2021

\section{References}

Andriani, A \& Wakhudin. (2020). Implementasi Pendidikan Karakter Melalui Model Pembelajaran Discovery Learning Di Mim Pasir Lor 
Karanglewas Banyumas. JPM: Jurnal Pengabdian kepada Masyarakat, 1 (2), 51-63. https://doi.org/10.32815/jpm.v1i2.303

Anoba, J. L. D. \& Cahapay, M. B. (2020). The Readiness of Teachers on Blended Learning Transition for Post-COVID-19 Period: An Assessment Using Parallel Mixed Method. PUPIL: International Journal of Teaching, Education and Learning, 4(2), 295-316.

http://dx.doi.org/10.20319/pijtel.2020.42.295316

Arka, I.W. (2020). Pengembangan Model Pembelajaran Inovatif Berbasis Kompetensi. Jurnal Widyacarya, 4 (2), 54-63. Retrieved from http://jurnal.stahnmpukuturan.ac.id/index.php/ widyacarya/article/view/792

Astra, I. M., Raihanati, R., \& Mujayanah, N. (2020). Development of Electronic Module Using Creative Problem-Solving Model Equipped with Hots Problems on The Kinetic Theory of Gases Material. Jurnal Penelitian \& Pengembangan Pendidikan Fisika, 6(2), 181-194. https://doi.org/10.21009 $\angle 1.06205$.

Carolin, Y., Saputro, S., \& Saputro, A. N. C. (2015). Penerapan Metode Pembelajaran Problem Solving dilengkapi LKS untuk Meningkatkan Aktivitas dan Prestasi Belajar pada Materi Hukum Dasar Kimia Siswa Kelas X MIA 1 SMA Bhinneka Karya 2 Boyolali Tahun Pelajaran 2014/2015. Jurnal Pendidikan Kimia, 4 (4), 46-53. Retrieved from https://jurnal.fkip.uns.ac.id/index.php/kimia/ar ticle/view/6569

Effendi, H., \& Hendriyani, Y. (2020). The Conceptual and Hypothetical Model of Interactive Blended Problem Based Learning. JPI (Jurnal Pendidikan Indonesia), 8(2), 285. https://doi.org/10.23887/jpiundiksha.v8i2.2416

Lestari, Y., Rahmad, M., \& Zulfarina. (2021). Needs Analysis of Problem-Solving Based Learning Video Development to Train Students' Concept Understanding. Jurnal Pendidikan Sains (JPS), 9(1), 81-90. https://doi.org/10.26714/jps.9.1.2021.81-90

Mentari, N., Komalasari, K., \& Samlawi, F. (2021). The use of laboratory social sciences as a resource of learning at junior high school 26 bandung. International Journal Pedagogy of Social Studies, 6(2), 65-72. https://doi.org/10.17509/ijposs.v6i2.28582

Mulyasa, E. (2016). Manajemen Pendidikan Karakter. Jakarta: Bumi Aksara.

Nikolopoulou, K., Gialamas, V., Lavidas, K. et al. Teachers' Readiness to Adopt Mobile Learning in Classrooms: A Study in Greece. Tech Know Learn 26, 53-77 (2021). https://doi.org/10.1007/s10758020-09453-7

Nurhafidhah, Hasby, dan Alvina, S. (2021). The Analysis of Student Character Values in The Use of Secondary Metabolic Utilization Lab Module.
Jurnal Ilmiah Peuradeun, 9(1), 179- 188. https://doi.org/10.26811/peuradeun.v9i1.484

Nurhafidhah, Yakob, M., \& Mauliza. (2018). Kajian Aspek Nilai Karakter pada Buku Ajar IPA. Jurnal Katalis, 1(1), 1-6. Retrieved from https://jurnal.unsam.ac.id/index.php/chemica/a rticle/view/991

Nurlaily, V.A., Soegiyanto, H., \& Usodo, B. (2019). Elementary school teacher's obstacles in the implementation of problem-based learning model in mathematics learning. Journal on Mathematics Education, 10(2), 229-238. https://doi.org/10. 22342/jme.10.2.5386.229-238

Partayasa, W. (2020). Pengaruh Model Pembelajaran Creative Problem Solving (CPS) Berbantuan Video Pembelajaran Terhadap Kemampuan Pemecahan Masalah ditinjau dari Minat. JNPM (Jurnal Nasional Pendidikan Matematika), 4(1), 168. https://doi.org/10.33603/jnpm.v4i1.2644.

Putri, D.E.N., Rudibyani, R.B., \& Efkar, T. (2015). Pembelajaran Problem Solving untuk Meningkatkan Keterampilan Inferensi dan Mengkomunikasikan Materi Larutan Penyangga. Jurnal Pendidikan dan Pembelajaran Kimia, 4(3), 10601072. Retrieved from http://jurnal.fkip.unila.ac.id/index.php/JPK/arti cle/view/11921

Sadia, I.W., Arnyana, I.B.P., \& Muderawan, I.W. (2013). Model Pendidikan Karakter Terintegrasi Pembelajaran Sains. Jurnal Pendidikan Indonesia, 2(2), 209-220. http://dx.doi.org/10.23887/jpiundiksha.v2i2.2165

Supriadi., Wildan., \& Laksmiwati, D. (2020). Implementasi Model Pembelajaran Berbasis Masalah dan Pengaruhnya Terhadap Perkembangan Karakter Mahasiswa. Jurnal Penelitian Pendidikan IPA (JPPIPA), 6(1), 63-68. https://doi.org/10.29303/jppipa.v6i1.323

Tanjung, R. \& Wibowo, W. (2013). Pengaruh Model Pembelajaran Problem Solving Terintegrasi Karakter terhadap Pembentukan Karakter dan Hasil Belajar Siswa Kelas X Pada Sub Materi Alat Ukur dan Daya Listrik Di SMA N 1 Hinai Langkat. Jurnal INPAFI, 1(2), 95-106. https://doi.org/10.24114/inpafi.v1i2.1997

Wijaya, H., \& Tulak, H. (2019). Pengembangan Model Pembelajaran Pendidikan Karakter Berbasis Media Sosial. Artikel Online. http://dx.doi.org/10.31219/osf.io/g68fs

Zaki, N. A. A., Zain, N. Z. M., Noor, N. A. Z. M., \& Hashim, H. (2020). Developing a conceptual model of learning analytics in serious games for stem education. Jurnal Pendidikan IPA Indonesia, 9(3), 330- 339. https:// doi.org/10.15294/jpii.v9i3.24466 